\title{
Physiological response of sweet corn (Zea mays Ls.) grown under sandy soil to a-tocopherol treatments and different irrigation systems
}

\author{
Elham Abd Elmoneim Badr ${ }^{1}$, Mervat Shamoon Sadak², Gehan Shaker Bakhoum ${ }^{{ }^{*}}$ (] \\ and Howida Hassan Ahmed Khedr ${ }^{1}$
}

\begin{abstract}
Background: Antioxidants or vitamins are organic compounds that are needed in tiny quantities and have stimulatory role on growth and productivity of different plants. Two field experiments were conducted in two summer seasons to investigate the role of two irrigation systems (spraying and dripping) and a-tocopherol foliar treatment with different concentrations (0,100 and $200 \mathrm{mg} / \mathrm{L}$ ) on some growth indices and physiological aspects, yield and its components of sweet corn plants.

Results: The results show that dripping irrigation system was more effective than Sprinkler system on increasing the studied growth indices and biochemical attributes as well as yield quantity and quality. The results also show the enhancing effect of different a-tocopherol treatments on growth indices, and yield quantity and quality of the sweet corn varieties via enhancing photosynthetic pigments, indole acetic acid, phenolics, carbohydrates constituents, free amino acids and proline contents. Moreover, the interaction between the two irrigation systems and different concentrations a-tocopherol showed that, dripping irrigation with $200 \mathrm{mg} / \mathrm{L}$ a-tocopherol was the most effective treatment on increasing growth, yield and yield components of sweet corn plants.
\end{abstract}

Conclusion: It could be concluded that dripping irrigation system was more effective than Sprinkler system on increasing the studied growth indices and physiological aspects, yield and its constituents. Moreover, treatment of maize plant with a-tocopherol could improve the studied growth indices, physiological aspects and consequently yield.

Keyword: Indole acetic acid, Productivity, Proline, Sweet corn, a-tocopherol, Total soluble sugars

\section{Background}

Maize plant (Zea mays L.) is one of the main staple cereal crops with a broad environmental and biological effectiveness. (Amal et al. 2016) stated that maize production was increased in sandy soils characterized by poor

\footnotetext{
*Correspondence: geh_shaker@yahoo.com

1 Field Crops Research Department, Agricultural and Biological Research Division, National Research Centre, 33th El Behooth St, P.O. 12622, Giza, Egypt

Full list of author information is available at the end of the article
}

fertility, increased $\mathrm{pH}$ and poor organic matter. Sweet corn (Moench) is a hybrid of maize plant having higher sucrose, kernel calcium as well as several mineral contents. Additionally, sweet corn crop is considered the fifth most cultivated cereal crop around the world as it is grown for ethanol production, forage, sugar, grain and fiber purposes (Yuan et al. 2008). Prominence of sweet corn cultivation between farmers is increased due to its short duration and increased economic returns. In addition, it provides high-quality fodder for milk animals, as well as supplying green cobs (Abebe et al. 2016). 
Moreover, sweet corn is gaining prominence in many countries as an alternative for biofuel production (Godsey et al. 2012) due to its high production of lignocellulosic biomass and fermentable sugars (Whitfield et al. 2012).

Agriculture is the primary user of available water resources. Nearly about 70 percent fresh water consumed by humans is for irrigation (Payero et al. 2006; Sepaskhah and Ahmadi 2010). Irrigation is a critical limitation factor in newly reclaimed areas as sandy soil in the New Valley, due to the scarcity of water resources, which causes serious crop damages (Hanson and May 2004). Therefore, there is a dire need to determine the optimum water requirement in order to reach the highest crop production with water rationalization. Increasing water productivity is particularly important in the regions with scarce water resources (Mahmud et al. 2003). The presence of appropriate moisture at the crucial plant growth stages is important to improve biochemical process of plant and enhance the performance of mineral nutrients added to crops, thus any extent of water deficit can cause reduced effects on growth and productivity of plant. Thus, improving irrigation efficiency is prerequisite in future, especially in sandy soil which suffer from water scarcity resulted from low precipitation, high evaporation rate and temperature fluctuation between day and night. Therefore, irrigation water has a major effect in agricultural practices in crop production. Earlier studies on sweet corn showed that leaf area and specific leaf area decreased under water deficit, (Munamava and Riddoch 2001). A significant improvement in plant and dry matter formation measured as grain and straw yields was recorded with the increasing levels of irrigation (Abdel-Motagally 2010). Afshar et al. (2014) stated that deficit irrigation reduced grain yield. Sher et al. (2013) noticed that the biomass traits and water use efficiency WUE were more influenced by water regimes, and similar trend was obtained by Fernandez et al. (2012). Also, Tawfik et al. (2018) noticed that water use efficiency significantly affected by irrigation requirements for all the studied bean cultivars.

Antioxidants or vitamins are natural and safety organic compounds that in low amounts exerted large effect on various biochemical processes of different crops. (Foyer et al. 1991). External treatment of vitamins has attained significant interest as a potential strategy for alleviating the reduced effects of various environmental conditions on plants (Munne-Bosch 2005; El Bassiouny et al. 2005). One of these compounds is $\alpha$ Tocopherol (vitamin E), it is a lipid soluble vitamin produced by various crops; its amounts differs in various cells and varies throughout growth and in relation to environmental adverse conditions. It maintains membranes, scavenges and quenches various reactive oxygen species (Maeda and Della Penna 2007), thus save polyunsaturated fatty acids from lipid peroxidation (Noctor 2006). In collaboration with the xanthophylls cycle, vitamin E performs two separate roles in chloroplasts at the two main reactive oxygen species formation sites: (Havaux et al. 2005; Kumar et al. 2012). Sadak and Dawood (2014) and Dawood et al. (2016) found that $\alpha$-tocopherol treatment on flax and faba bean increased their growth and productivity.

The objective of this work was to study the effect of two irrigation methods (Sprinkler system and dripping system) and foliar treatment with three levels of $\alpha$-tocopherol (TOC) on sweet corn plant growth and productivity. In addition, investigate the interactive effects of irrigation methods and TOC treatments on growth, some biochemical aspects and yield of sweet corn plants grown under sandy soil.

\section{Methods}

Two field experiments were carried out at the Agricultural Production and Research Station, National Research Center, Nubaria Province, Behaira Governorate, Egypt, during the two successive summer seasons of 2018 and 2019. Sweet corn (Zea mays L.) cv., Dorado seeds were obtained from Ministry of Agricultural. Seeds were sown on 10th and 12th of May of 2018 and 2019, respectively. Soil of the experimental site was sandy soil. Mechanical, chemical and nutritional properties of the experimental soil site (30 depths) reported in Table 1 were analyzed according to (Chapman and Pratt 1978).

The experimental design of the study was split plot design with three replications, where irrigation systems (Sprinkler and dripping) allocated in the main plots were foliar treatment twice during vegetative growth stage (after 45 and 60 days from sowing) with $\alpha$ Tocopherol (control, 100 and $200 \mathrm{mg} / \mathrm{L}$ ) was allocated in the subplots. The plot area was $21 \mathrm{~m}^{2}\left(5^{*} 4.20\right)$ with 6 ridges of $5 \mathrm{~m}$ in length and $70 \mathrm{~cm}$ in width. Phosphorus fertilizer was added before sowing at rate of $150 \mathrm{~kg}$ calcium super phosphate $\left(15.5 \% \mathrm{P}_{2} \mathrm{O}_{2} /\right.$ fed). Plant samples were taken after 75 days from sowing to determine the following

Table 1 Physical and chemical analyses of soil

\begin{tabular}{lllr}
\hline Physical properties & \multicolumn{3}{c}{ Chemical properties } \\
\hline Sand\% & 91.2 & Organic matter \% & 0.3 \\
Silt \% & 4.0 & E.C mmhos/cm & 0.3 \\
Clay \% & 4.8 & PH & 7.4 \\
$\mathrm{CaCO}_{3}$ & 1.3 & Soluble N ppm & 7.7 \\
Soil texture & Sandy & Available P ppm & 2.9 \\
& & Exchange K ppm & 19.8 \\
\hline
\end{tabular}


growth characters, plant height $(\mathrm{cm})$, weight of (leaves and stem (gm)), number of leaves/plant, total dry and fresh weight of plant (gm) and Leaves Area $\left(\mathrm{dm}^{2}\right)$ according to "(Radford 1967)". At harvest, ten guarded plants were taken at random the middle of each plot to determined yield characters as plant height $(\mathrm{cm})$, number of (plant and leaves), weight of (leaves, shoot, steam and plant) (gm) and weight of (grain/plot (gm), (kg/fed).

\section{Chemical analysis}

\section{Photosynthetic pigments}

Total chlorophyll a and b and carotenoids contents in fresh leaves of lupines plant were estimated using the method of Lichtenthaler and Buschmann (2001). The fresh tissue was ground in a mortar and pestles using $80 \%$ acetone. The optical density (OD) of the solution was recorded at 662 and $645 \mathrm{~nm}$ (for chlorophyll a and $\mathrm{b}$, respectively) and $470 \mathrm{~nm}$ (for carotenoids) using a spectrophotometer (Shimadzu UV-1700, Tokyo, Japan). The values of photosynthetic pigments were expressed in $\mathrm{mg} / \mathrm{g}$ FW.

\section{Indole acetic acid content}

A known weight of the fresh samples was taken and extracted with $85 \%$ cold methanol $(\mathrm{v} / \mathrm{v})$ for three times at $0{ }^{\circ} \mathrm{C}$. The combined extracts were collected and made up to a known volume with cold methanol. Then take $1 \mathrm{ml}$ of the methanolic extract and $4 \mathrm{ml}$ of PDAB reagent (para-dimethylamino benzoic acid $1 \mathrm{~g}$ dissolve in $50 \mathrm{ml} \mathrm{HCl}, 50 \mathrm{ml}$ of ethanol 95\%) and left for $60 \mathrm{~min}$ in $30-400{ }^{\circ} \mathrm{C}$. The developing color was spectophotometrically measured ${ }^{33}$ at wave length of $530 \mathrm{~nm}$. As described by Larsen et al. (1962).

\section{Total phenol content}

The extract was extracted as IAA extraction, and then $0.5 \mathrm{ml}$ of the extraction was added to $0.5 \mathrm{ml}$ Folin, shaked and allowed to stand for $3 \mathrm{~min}$. Then, one $\mathrm{ml}$ of saturated sodium carbonate was added to each tube followed by distilled water shaken and allowed to stand for $60 \mathrm{~min}$. The optical density was determined at wave length of $725 \mathrm{~nm}$ using spectrophotometer as described by Danil and George (1972).

\section{Total carbohydrate}

Determination of total carbohydrates was carried out according Herbert et al., (1971). A known mass (0.2$0.5 \mathrm{~g}$ ) of dried tissue was placed in a test tube, and then $10 \mathrm{ml}$ of sulfuric acid $(1 \mathrm{~N})$ was added. The tube was sealed and placed overnight in an oven at $100{ }^{\circ} \mathrm{C}$. The solution was then filtered into a measuring flask $(100 \mathrm{ml})$ and completed to the mark with distilled water. The total sugars were determined Colorimeterically according ${ }^{40}$ as follows: An aliquot of $1 \mathrm{ml}$ of sugar solution was transferred into test tube and treated with $1 \mathrm{ml}$ of $5 \%$ aqueous phenol solution followed by $5.0 \mathrm{ml}$ of concentrated sulfuric acid. The tubes were thoroughly shaken for ten minutes then placed in a water bath at $23-30{ }^{\circ} \mathrm{C}$ for $20 \mathrm{~min}$. The optical density of the developed color was measured at $490 \mathrm{~nm}$ using Shimadzu spectrophotometer model UV 1201.

\section{Free amino acids}

Free amino acid and proline contents were extracted according to the method described by Vartainan et al. (1992). Free amino acid was determined with the ninhydrin reagent method described by Yemm and Coocking, (1955). Further, 1.0-ml acetate buffer ( $\mathrm{pH} 5.4)$ and 1.0$\mathrm{ml}$ chromogenic agent were added to $1.0-\mathrm{ml}$ free amino acid extraction. The mixture was heated in boiling water bath for $15 \mathrm{~min}$. After cooled in tap water, 3-ml ethanol $(60 \% \mathrm{v} / \mathrm{v})$ was added. The absorbance at $570 \mathrm{~nm}$ was then monitored using Spekol Spectrocolorimeter VEB Carl Zeiss.

\section{Proline}

Proline was assayed according to the method described by Bates et al. (1973). $2 \mathrm{ml}$ of proline extract, $2 \mathrm{ml}$ of acid ninhydrin and $2 \mathrm{ml}$ of glacial acetic acid were added and incubated for $1 \mathrm{~h}$ in a boiling water bath followed by an ice bath. The absorbance was measured at $520 \mathrm{~nm}$ using Spekol Spectrocolorimeter VEB Carl Zeiss. A standard curve was obtained using a known concentration of authentic proline.

\section{Polysaccharides}

Polysaccharides were determined according to Naguib (1963)

\section{Statistical analysis}

Data were subjected to statistical analysis of variance as described by Snedecor and Cochran (1990). Mean values of the recorded data were compared by using the least significant differences (L.S.D at 0.05).

\section{Results}

\section{Changes in growth indices}

The combined analysis of the obtained data of the effect of different irrigation systems i.e., Sprinkler irrigation or dripping irrigation on growth indices of sweet corn plants are presented in Table 2. Data clearly show that drip irrigation was superior to Sprinkler irrigation on different growth indices (plant height $\mathrm{cm}$, leaves number and area LA $\left(\mathrm{cm}^{2}\right)$ per plant, fresh weight of leaves, stem and total plant (g) as well as total dry weight of plant (g)) of sweet corn plants grown under sandy soil. 
Table 2 Effect of irrigation system and a-tocopherol foliar spray on growth attributes in sweet corn plant in sandy soil conditions (combined analysis of two seasons)

\begin{tabular}{|c|c|c|c|c|c|c|c|}
\hline \multirow[t]{2}{*}{ Treatment } & \multirow[t]{2}{*}{ Plant height $(\mathrm{cm})$} & \multirow{2}{*}{$\begin{array}{l}\text { Leaves number/ } \\
\text { plant }\end{array}$} & \multirow[t]{2}{*}{$\mathrm{LA}\left(\mathrm{cm}^{2}\right)$} & \multicolumn{3}{|c|}{ Fresh weight of (gm) } & \multirow{2}{*}{$\begin{array}{l}\text { Total dry } \\
\text { weight } \\
\text { (gm) }\end{array}$} \\
\hline & & & & Leaves & Stem & Total & \\
\hline \multicolumn{8}{|c|}{ Irrigation system } \\
\hline Sprinkler & 90.23 & 8.66 & 197.12 & 20.97 & 39.50 & 60.47 & 31.90 \\
\hline Dripping & 100.19 & 7.84 & 202.97 & 26.16 & 44.20 & 70.36 & 36.69 \\
\hline L.S.D at $5 \%$ & 2.36 & 0.57 & 3.34 & 1.61 & 1.41 & 2.68 & 1.96 \\
\hline \multicolumn{8}{|c|}{ a-Tocopherol concentration } \\
\hline Control & 93.97 & 8.05 & 194.77 & 27.88 & 36.19 & 64.07 & 31.77 \\
\hline $100 \mathrm{mg} / \mathrm{L}$ & 98.21 & 4.48 & 216.98 & 28.46 & 42.3 & 70.75 & 36.08 \\
\hline 200 mg/L & 102.45 & 8.20 & 218.39 & 29.36 & 47.06 & 76.42 & 42.53 \\
\hline L.S.D at $5 \%$ & 3.28 & 0.26 & 6.08 & 2.04 & 1.87 & 3.13 & 2.14 \\
\hline \multicolumn{8}{|l|}{ Interaction } \\
\hline \multicolumn{8}{|l|}{ Sprinkler } \\
\hline Control & 94.67 & 7.66 & 179.79 & 20.28 & 35.95 & 36.22 & 27.85 \\
\hline 100 mg/L & 87.17 & 7.18 & 196.04 & 22.48 & 40.13 & 62.61 & 33.95 \\
\hline 200 mg/L & 88.85 & 8.66 & 215.52 & 20.16 & 42.43 & 62.59 & 33.9 \\
\hline \multicolumn{8}{|l|}{ Dripping } \\
\hline Control & 100.78 & 8.44 & 209.76 & 35.49 & 36.44 & 71.92 & 35.69 \\
\hline 100 mg/L & 107.56 & 8.30 & 221.25 & 34.43 & 44.46 & 78.89 & 38.21 \\
\hline 200 mg/L & 110.22 & 9.22 & 237.92 & 38.56 & 51.7 & 90.25 & 51.17 \\
\hline L.S.D at $5 \%$ & 4.64 & 0.36 & 8.6 & 2.89 & 2.64 & 4.42 & 3.02 \\
\hline
\end{tabular}

Regarding exogenous application of $\alpha$-tocopherol with different concentrations in Table 2 shows that $\alpha$-tocopherol foliar treatments with different concentrations significantly increased growth indices of sweet corn plants comparing with control. Moreover, foliar treatment with higher concentration of $\alpha$-tocopherol $(200 \mathrm{mg} / \mathrm{L})$ caused the highest values of all examined growth indices compared with other treatments (control and $100 \mathrm{mg} / \mathrm{L}$ ).

The interaction effect between irrigation systems and application of $\alpha$-tocopherol foliar spray exerted also significant influence on plant height, number of leaves, LA and weight of leaves, stem and total fresh weight as well as total dry in Table 2. Foliar treatment with 100 and $200 \mathrm{mg} / \mathrm{L}$ of $\alpha$-tocopherol caused significant increases in different growth indices as compared with their corresponding controls either with Sprinkler irrigation and drip irrigation systems (Table 2). Moreover, foliar treatment with different $\alpha$-tocopherol concentrations caused higher increases in growth parameters of sorghum plants irrigated by dripping irrigation system more than Sprinkler system. In general, the highest values of the studied growth indices were obtained by foliar treatment with higher concentration of $\alpha$ tocopherol $(200 \mathrm{mg} / \mathrm{l})$ and irrigated by drip irrigation system.

\section{Changes in photosynthetic pigments, indole acetic acid} (IAA) and phenolic contents

Table 3 shows the effect of irrigation system and/or foliar treatment with $\alpha$-tocopherol on photosynthetic pigments, indole acetic acid and phenolic contents of sweet corn plants grown under sandy soil. Data clearly show that there is significant difference between Sprinkler and dripping irrigation systems on photosynthetic pigments (Chl $a$, Chl $b$, carotenoids and total pigments), indole acetic acid (IAA) and phenolic contents of sweet corn plants. Moreover, Table 3 data clearly demonstrate that dripping irrigation was superior over Sprinkler irrigation on photosynthetic, indole acetic acid (IAA) and phenolic contents.

Different concentrations of $\alpha$-tocopherol increased significantly the above-mentioned parameters (Table 3 ) as compared with control plants. $\alpha$-Tocopherol with $200 \mathrm{mg} / \mathrm{L}$ caused the highest improving effects of sweet corn plants.

Regarding to the interaction between foliar treatment of $0.0,100$ and $200 \mathrm{mg} / \mathrm{L} \alpha$-tocopherol and different irrigation systems (Table 3). Data presented in Table 3 revealed that the interaction between foliar treatment of $0.0,100$ and $200 \mathrm{mg} / \mathrm{L} \alpha$-tocopherol and different irrigation systems caused significant increases in the 
Table 3 Effect of irrigation system and a-tocopherol foliar spray on photosynthetic pigments, indole acetic acid (IAA) and phenol contents of leaves and shoots of sweet corn plant grown under sandy soil conditions

\begin{tabular}{|c|c|c|c|c|c|c|}
\hline \multirow[t]{2}{*}{ Treatment } & \multicolumn{4}{|c|}{$\mathrm{mg} / \mathrm{g}$ fresh weight } & \multicolumn{2}{|c|}{$\mathrm{mg} / 100 \mathrm{~g}$ dry $\mathrm{w}$} \\
\hline & Chlo a & Chlo b & Carto & Total pig & IAA & Phenol \\
\hline \multicolumn{7}{|c|}{ Irrigation system } \\
\hline Sprinkler & 0.83 & 0.42 & 0.26 & 1.51 & 26.88 & 52.14 \\
\hline Dripping & 1.12 & 0.49 & 0.31 & 1.92 & 33.96 & 60.4 \\
\hline L.S.D at $5 \%$ & 0.14 & 0.01 & 0.01 & 0.03 & 0.94 & 0.83 \\
\hline \multicolumn{7}{|c|}{ a-Tocopherol concentration } \\
\hline Control & 0.72 & 0.40 & 0.25 & 1.37 & 25.02 & 51.13 \\
\hline $100 \mathrm{mg} / \mathrm{L}$ & 1.01 & 0.46 & 0.28 & 1.75 & 30.52 & 56.04 \\
\hline 200 mg/L & 1.20 & 0.51 & 0.33 & 2.04 & 35.71 & 61.64 \\
\hline L.S.D at $5 \%$ & 0.12 & 0.01 & 0.007 & 0.015 & 0.49 & 0.44 \\
\hline \multicolumn{7}{|l|}{ Interaction } \\
\hline \multicolumn{7}{|l|}{ Sprinkler } \\
\hline Control & 0.69 & 0.37 & 0.23 & 1.29 & 21.24 & 48.32 \\
\hline 100 mg/L & 0.84 & 0.42 & 0.26 & 1.52 & 27.09 & 51.98 \\
\hline 200 mg/L & 0.96 & 0.47 & 0.29 & 1.72 & 32.3 & 56.11 \\
\hline \multicolumn{7}{|l|}{ Dripping } \\
\hline Control & 0.75 & 0.43 & 0.27 & 1.45 & 28.81 & 53.94 \\
\hline 100 mg/L & 1.17 & 0.50 & 0.30 & 1.97 & 33.95 & 60.09 \\
\hline 200 mg/L & 1.44 & 0.54 & 0.36 & 2.34 & 39.11 & 67.16 \\
\hline L.S.D at $5 \%$ & 0.164 & 0.014 & 0.001 & 0.11 & 0.69 & 0.62 \\
\hline
\end{tabular}

photosynthetic pigments constituents, IAA and phenol contents of sweet corn plants as compared with their corresponding controls. Different $\alpha$-tocopherol concentrations under dripping irrigation was more effective than under Sprinkler irrigation as it caused significant increases in different studied parameters. Sweet corn plants grown under dripping irrigation and treated with $200 \mathrm{mg} / \mathrm{L} \alpha$ tocopherol gave the highest increasings in above-mentioned parameters.

\section{Changes in carbohydrates constituents, free amino acids and proline contents}

Table 4 shows the effect of irrigation system on carbohydrates constituents (total soluble sugars, polysaccharides and total carbohydrates), free amino acids and proline of sweet corn plant in sandy soil. Data show the presence of significant differences between the studied two irrigation systems. Meanwhile, drip irrigation gave the highest total carbohydrates constituents, free amino acids and proline contents.

The role of $\alpha$-tocopherol $(0.0,100$ and $200 \mathrm{mg} / \mathrm{L})$ on carbohydrates constituents, free amino acids and proline contents of sweet corn leaves are presented in Table 4 . Moreover, different treatments significantly increased the above-mentioned parameters. The most effective treatment was $200 \mathrm{mg} / \mathrm{L}$ on increasing carbohydrate constituents, free amino acids and proline contents of sweet corn plants.

Table 4 shows that various $\alpha$-tocopherol treatments significantly increased the above-mentioned parameters of sweet corn either in plants irrigated with spray irrigation system or dripping irrigation system. The most effective treatment was $200 \mathrm{mg} / \mathrm{L}$. $\alpha$-Tocopherol treatment of $200 \mathrm{mg} / \mathrm{L}$ in drip irrigation treatment gave the highest increments on carbohydrates constituents (TSS, polysaccharides and total carbohydrates), free amino acids and proline contents.

\section{Changes in yield attributes}

Data in Table 5 indicate that the two used irrigation systems (Sprinkler and dripping) show significant differences in yield and yield attributes of sweet corm grown under sandy soil. The results showed that dripping irrigation system gave higher values of grain yield and protein\% (790.17 (gm), $301.02(\mathrm{~kg} / \mathrm{fed})$ and (9.56\%) compared with Sprinkler irrigation system ( $361.06 \mathrm{~g}$ and $137.55 \mathrm{~kg} / \mathrm{fed})$.

The results presented in Table 5 also indicated that the yield and its attributes were significantly increased by foliar application of $\alpha$-tocopherol with different concentration $(100,200 \mathrm{mg} / \mathrm{L})$ as compared with untreated control plants. Meanwhile, the high concentration of $\alpha$-tocopherol foliar treatment gave the highest values of all studied yield attributes. 
Table 4 Effect of irrigation system and a-tocopherol foliar spray on TSS, polysaccharides, total carbohydrate (mg/g dry wt), free amino acids and proline content (mg/g 100 dry wt) on Sweet corn plant grown under sandy soil conditions

\begin{tabular}{|c|c|c|c|c|c|}
\hline Treatment & $\begin{array}{l}\text { Carbohydrates } \\
\text { mg/g dry weight }\end{array}$ & TSS & Polysaccharides & $\begin{array}{l}\text { Free amino acid } \\
\mathrm{mg} / 100 \mathrm{~g} \text { dry weight }\end{array}$ & Proline \\
\hline \multicolumn{6}{|c|}{ Irrigation systems } \\
\hline Sprinkler & 311.81 & 28.02 & 383.39 & 98.56 & 12.63 \\
\hline Dripping & 317.81 & 28.56 & 289.79 & 100.59 & 13.99 \\
\hline L.S.D at $5 \%$ & 0.84 & 0.52 & 0.81 & 0.113 & 0.562 \\
\hline \multicolumn{6}{|c|}{ a-Tocopherol concentration } \\
\hline Control & 298.36 & 27.54 & 269.09 & 79.23 & 11.4 \\
\hline $100 \mathrm{mg} / \mathrm{L}$ & 315.29 & 28.00 & 287.29 & 106.12 & 13.32 \\
\hline 200 mg/L & 330.97 & 29.27 & 303.38 & 113.52 & 15.21 \\
\hline L.S.D at $5 \%$ & 1.87 & 0.41 & 1.74 & 0.358 & 0.144 \\
\hline \multicolumn{6}{|l|}{ Interaction } \\
\hline \multicolumn{6}{|l|}{ Sprinkler } \\
\hline Control & 296.55 & 28.62 & 266.63 & 78.77 & 10.88 \\
\hline $100 \mathrm{mg} / \mathrm{L}$ & 312.67 & 27.77 & 284.44 & 104.69 & 13.04 \\
\hline $200 \mathrm{mg} / \mathrm{L}$ & 326.62 & 27.67 & 299.1 & 112.22 & 13.98 \\
\hline \multicolumn{6}{|l|}{ Dripping } \\
\hline Control & 300.17 & 27.52 & 271.55 & 79.68 & 11.92 \\
\hline 100 mg/L & 317.91 & 28.23 & 290.14 & 107.56 & 13.61 \\
\hline 200 mg/L & 335.33 & 29.92 & 307.66 & 114.47 & 16.43 \\
\hline L.S.D at $5 \%$ & 2.65 & 0.561 & 2.47 & 0.506 & 0.204 \\
\hline
\end{tabular}

The interaction between irrigation systems and application of $\alpha$-tocopherol foliar spraying exerted also significant increases on all yield and yield attributes of sweet corn plants as compared with untreated control plants (Table 5). External application of $\alpha$-tocopherol with 100 and $200 \mathrm{mg} / \mathrm{L}$ and dripping irrigation system were more effective than with Sprinkler irrigation system on increasing yield and its attributes of sweet corn plants as compared with their untreated controls. (Table 5). In general, the highest values of plant height, number of plant and weight as well as leaves, shoss, stem, grain of plant, grain yield and protein $\%(109.92 \mathrm{~cm}, 35.33,16.29 \mathrm{~g}, 5.74 \mathrm{~g}$, $43.95 \mathrm{~g}, 926.59 \mathrm{~g}, 352.98 \mathrm{~kg} / \mathrm{fed}$ and $9.88 \%)$, respectively, were obtained from high concentration $\alpha$ tocopherol $(200 \mathrm{mg} / \mathrm{l})$ and irrigated by dripping irrigation system.

\section{Discussion}

Data in Table 2 clearly show that drip irrigation was superior to Sprinkler irrigation on different growth indices of sweet corn plants grown under sandy soil. These results might be because dripping irrigation which used day after day via drip irrigation system resulted in maintaining soil water around root. Badawi et al. (1988), Ibrahim and El-Hosary (1992) and Khattab et al. (2016) confirmed these results on different plant species.

Data in Table 3 clearly show there is significant differences between Sprinkler and dripping irrigation systems on photosynthetic pigments, indole acetic acid (IAA) and phenolic contents of sweet corn plants. Moreover, Table 3 data clearly demonstrates that dripping irrigation was superior over Sprinkler irrigation on photosynthetic. Data in Table 5 indicates that the two used irrigation systems (Sprinkler and dripping) show significant differences in yield and yield attributes of sweet corm grown under sandy soil.

These obtained results agree with Colaizzi (2004) and Abdelaziz et al. (2018). These increases in different studied yield and its attributes might be due to drip irrigation may keep the water contents around root system in root zone around field capacity and prevent water deficiency especially at reproduction stage. Thus, the increased available water might enhance mineral absorption and photosynthetic metabolic transportation from leaves to seeds. Thus, the beneficial effect of the available soil moisture is reflected favorably on grain yield and its attributes and vice versa. These results are in accordance with those obtained by Ragheb et al. (2000), El-Nagar (2003) and Khattab et al. (2016). Panel et al. (2006) stated that sweet corn had a tendency for absorbing water from deeper soil layers than maize.

Table 2 show that $\alpha$-tocopherol foliar treatments with different concentrations increased significantly growth indices of sweet corn plants. These obtained data are in accordance with El Hariri et al. (2010) and Kumar 


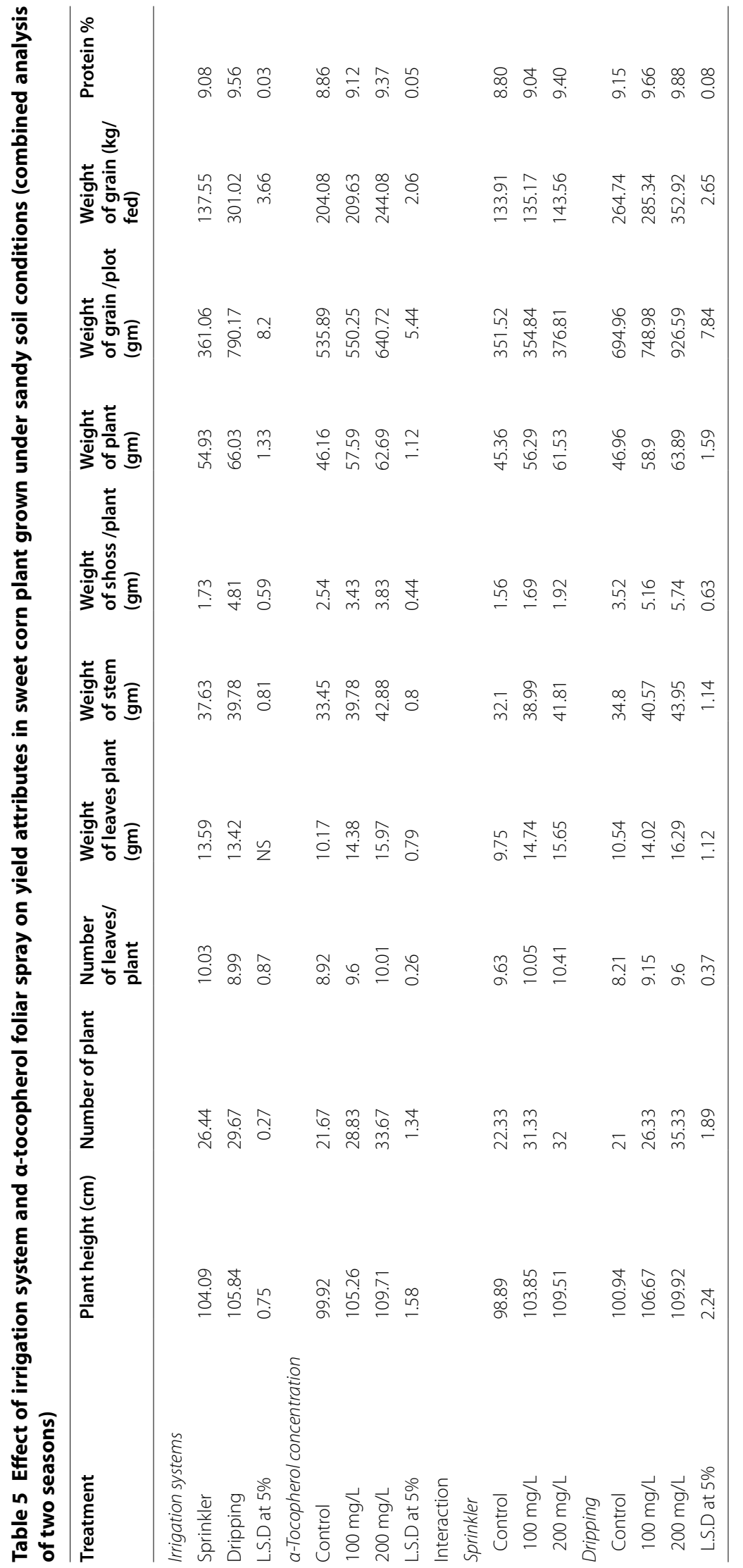


et al. (2012) on flax and wheat plants, respectively. $\alpha$-Tocopherol affect positively on various biochemical processes (El-Hariri et al. 2010). Moreover, foliar application of $\alpha$-tocopherol improves mineral absorption from soil and consequently increases their contents in leaves (Buschmann and Lichtenthaler, 1979).

Different treatments of $\alpha$-tocopherol caused significant increases in photosynthetic pigments, IAA and phenolic contents compared with control plants. The enhancement roles of $\alpha$ tocopherol on photosynthetic pigments in Table 3 in agreement with Al Qubaie (2012), Dawood et al. (2013), Rady et al. (2015) and Dawood et al. (2016) on sunflower, flax, soybean and faba bean plants. The improving effect of tocopherol on photosynthetic pigments contents of sweet corn might be resulted from stimulation of their biosynthesis and/or reduced their degradation. These promotive role of $\alpha$-tocopherol might be due to the role of $\alpha$-tocopherol on protection of chloroplast walls from photo-oxidation and provide a suitable environment for photosynthetic machinery (Hassan et al. 2013), maintains thylakoid membrane structure and function during plant development (Munne-Bosch and Alegra 2002; Munne'-Bosch 2005). With respect to indole acetic acid contents, foliar spray of $\alpha$-tocopherol increase contents of indole acetic acid (IAA) as compared to control plant this increase are related with growth indices improvement (Table 2). Rady et al. (2015) assumed that $\alpha$ - tocopherol increased indole acetic acid IAA contents of soybean plant.

Phenols have an important effect on balancing of plant metabolism and plant growth (Lewis \& Yamamoto 1990) and considered as a substrate for various antioxidant enzymes. The obtained data show significant increases in phenol contents of sweet corn plants in response to foliar treatment with $\alpha$-tocopherol different concentrations and the two used irrigation systems either spraying irrigation system or dripping irrigation system. Rady et al. (2011) on sunflower plant and Hussien et al. (2015) on cotton plant confirmed these results.

Table 4 shows the changes in carbohydrates constituents, free amino acids and proline contents of sweet corn in response to different irrigation systems. Moreover, treatments of $\alpha$-tocopherol increased significantly the studied parameters. The most effective treatment was $200 \mathrm{mg} / \mathrm{L}$ on increasing carbohydrate constituents, free amino acids and proline contents of sweet corn plants. Khan et al. (2011) mentioned that foliar spray of vitamins enhanced the biosynthesis of chlorophyll molecules which used in increasing photosynthetic metabolites, thus lead to the increase in various soluble sugars and nitrogen units' contents. Sadak et al. (2010) showed that treatment sunflower with $\alpha$-tocopherol caused increases in total carbohydrates, stimulation of protein synthesis and delaying senescence of sunflower plant. Moreover, vitamin $E$ ( $\alpha$-tocopherol) applications improved the accumulation of total soluble sugars in sweet corn either by improving contents some bioregulators (as indole acetic acid IAA) or by inducing carbohydrates synthesis (Rady et al. 2011). The biosynthesis and over production of free amino acids and organic solutes such as total soluble sugars TSS and proline in plant cells cause reduction in the osmotic potential, help retain water, and improve plant tolerance to different environmental unsuitable conditions (Lee et al. 2008).

Data presented in Table 5 also indicated that the yield and its attributes were significantly increased by foliar application of $\alpha$-tocopherol with different concentration $(100,200 \mathrm{mg} / \mathrm{L})$ as compared with untreated control plants. Meanwhile, the high concentration of $\alpha$-tocopherol foliar treatment gave the highest values of all studied yield attributes. The obtained results are coincide with the earlier results of Sadak and Dawood (2014) on flax and Dawood et al. (2016) on faba bean. These increases in sweet corn yield and yield attributes by $\alpha$-tocopherol foliar treatments could be attributed to its effect as antioxidant and enhancing protein synthesis and delaying senescence as suggested by Sadak et al. (2010) and Dawood et al. (2013). Likewise, the increase in seed yield is probably referred to the role of the applied plant antioxidant in improving nutrient uptake from soil and subsequently increasing plant growth, increasing photosynthetic rate and consequently seed yield (Dawood et al. 2016). Similar results obtained by Özbay and Ylldırım (2018) work on sugar beet, they reported that drip irrigation system have more effect on the root and yield with fertilization by foliar spray of micronutrients.

\section{Conclusion}

It might be deduced that dripping irrigation system was more effective than Sprinkler system on increasing the studied growth indices and biochemical attributes as well as yield quantity and quality. Different $\alpha$-tocopherol treatments improved growth and yield quantity and quality of the sweet corn via enhancing some biochemical aspects. Moreover, interaction between the two irrigation systems and different concentrations $\alpha$-tocopherol showed that dripping irrigation with $200 \mathrm{mg} / \mathrm{L} \alpha$-tocopherol was the most effective treatment on increasing growth, yield and yield components of sweet corn plants.

\section{Abbreviations \\ TOC: a-Tocopherol; LA: Leaves area; IAA: Indole acetic acid; WUE: Water use efficiency; Chl a: Chlorophyll a; Ch/ b: Chlorophyll b; TSS: Total soluble sugars.}

Acknowledgements

Not applicable. 


\section{Authors' contributions}

$E A B$, designed and farmed plants, and contributed to the statistical analysis. MShS, designed and performed the experiment, and was responsible of all the physiological and biochemical analysis. GShB, designed and farmed plants, and contributed to the statistical analysis. and HHK, designed and farmed plants, and contributed to the statistical analysis. All authors share in every step of this work and all of them contribute in writing the manuscript. All authors read and approved the final manuscript.

\section{Funding}

Not applicable.

\section{Availability of data and materials}

Not applicable.

\section{Ethics approval and consent to participate}

Not applicable.

\section{Consent for publication}

Not applicable.

\section{Competing interests}

The authors declare that they have no competing interests.

\section{Author details}

${ }^{1}$ Field Crops Research Department, Agricultural and Biological Research Division, National Research Centre, 33th El Behooth St, P.O. 12622, Giza, Egypt.

2 Botany Department, Agricultural and Biological Research Division, National Research Centre, 33th El Behooth St, P.O. 12622, Giza, Egypt.

Received: 19 June 2020 Accepted: 6 December 2020 Published online: 06 January 2021

\section{References}

Abdel-Motagally FMF (2010) Evaluation of water use WUE under different water regimes in grain sorghum (Sorghum bicolor $\mathrm{L}$ Monech). World J Agric Sci 6(5):499-505

Abdelaziz NM, Islam A, Mesbah AO, Garcia y Garcia A, (2018) Effect of irrigation and nitrogen fertilization strategies on silage corn grown in semi-arid conditions. Agronomy 8:208

Abebe Z, Dabala C, Birhanu T (2016) System productivity as influenced by varieties and temporal arrangement of bean in maize-climbing bean intercropping. J Agron 16(1):1-11

Afshar RK, Jovini MA, Chaichi MR, Hashemi M (2014) Grain sorghum response to arbuscular mycorrhiza and phosphorus fertilizer under deficit irrigation. Am Soc Agron 106(4):1212-1218

Al Qubaie Al (2012) Response of sunflowers cultivar Giza 102 (Helianthus annuus L) plants to spraying some antioxidants. Nature Sci 10:1-6

Amal G, Nabila A, Zaki M, Hassanein MS, Sh G, Tawifk MM (2016) Influence of nitrogen fertilizer sources on yield and its components of some maize varieties. RJPBCS 7(4):1005

Badawi MA, Attia AN, Sultan MS (1988) Growth and yield components of maize (Zea mays L.) as affected by irrigation quantities and antitranspirant treatment. Proc 3rd Conf Agric Kafr El Sheikh, Tanta Univ 1:69-77

Bates LS, Waldan RP, Teare LD (1973) Rapid determination of free proline under water stress studies. Plant Soil 39:205-207

Buschmann C, Lichtenthaler HK (1979) The influence of phytohormones on prenyllipid composition and photosynthetic activities of thylakoids. In: Appelgvist LA, Lilj Enberg C (eds) Advances in biochemistry and physiology of plant lipids. Elsevier, Amsterdam, pp 145-150

Chapman HD, Pratt RF (1978) Methods analysis for soil, plant and water. Univ. of California Div. Agric. Sci. 16-38

Colaizzi PDAD, Schneider SR, Evett TA (2004) Howell comparison of sdi, lepa, and spray irrigation performance for grain sorghum. ASAE. 47(5):1477-1492

Danil AD, George CM (1972) Peach seed dormancy in relation to endogenous inhibitors and applied growth substances. J Am Soc Hortic Sci $17: 621-624$
Dawood MG, El-Metwally IM, Abdelhamid MT (2016) Physiological response of lupine and associated weeds grown at salt-affected soil to a-tocopherol and hoeing treatments. Gesunde Pflanzen 68:117-127. https://doi.org/10.1007/s10343-016-0367-3

Dawood MG, El-Lethy Safaa R, Sadak Mervat Sh (2013) Role of methanol and yeast in improving growth, yield, nutritive value and antioxidants of soybean. World Appl Sci J 26(1):6-14

ELBassiouny HMS, Gobarah ME, Ramadan AA (2005) Effect of antioxidants on growth, yield and favism causative agents in seeds of Vicia faba $L$ plants grown under reclaimed sandy soil. J Agron 4:281-287

El Hariri DM, Mervat Sh, Sadak HMS, El-Bassiouny. (2010) Response of flax cultivars to ascorbic acid and a-tocopherol under salinity stress conditions. Inter J Acad Res 2(6):101-109

El-Nagar G. R. (2003) Integrating of mineral and bio-fixed nitrogen fertilization in maize production under different irrigation regimes. Assiut J Agric Sci 34(5):53-76

Fernandez CJ, Fromme DD, Grichar WJ (2012) Grain sorghum response to row spacing and plant populations in the Texas Coastal Bend Region. Int J Agron 2012:1-6

Foyer Ch, Lelandais M, Edwards EA, Mulineawx PM (1991) The role of ascorbate in plants, interactions with photosynthesis and regulatory significance. In: Pell EJ, Steffen KL (eds) Active oxygen oxidative stress and plant metabolism Current Topics in plant physiology, vol 6. American Society of Plant Physiologists. Rockville, MD, pp 131-144

Godsey CB, Linneman J, Bellmer D, Huhnke R (2012) Developing row spacing and planting density recommendations for rainfed sweet sorghum production in the southern plains. Agron J 104:280-286

Hanson B, May D (2004) Effect of subsurface drip irrigation on processing tomato yield, water table depth, soil salinity, and profitability. Agric Water Manag 68:1-17

Hassan NMK, Shafeek MR, Saleh SA, ELGreadly NHM (2013) Growth, yield and nutritional values of onion (Allium cepa L.) plants as affected by bioregulators and Vitamin E under newly reclaimed lands. J Appl Sci Res 9:795-803

Havaux M, Eymery F, Porfirova S, Rey P, Do“rmann, P. (2005) Vitamin E protects against photoinhibition and photooxidative stress in Arabidopsis thaliana. Plant Cell 17:3451-3469

Herbert D, Phipps PJ, Strange RE (1971) Chemical analysis of microbial cells. Methods Microbiol 5B:209-344

Hussien HA, Salem H, Mekki BE (2015) Ascorbate-glutathione tocopherol triad enhances antioxidant systems in cotton plants grown under drought stress. Int J Chem Tech Res 8(4):1463-1472

Ibrahim ME, El-Hosary HM (1992) Effect of irrigation intervals and plant density on some varieties of corn. Menufiya J Agric Res 17(3):1083-1093

Khan TA, Mazid M, Mohammad F (2011) A review of ascorbic acid potentialities against oxidative stress induced in plants. J Agrobiol 28:97-111

Khattab EA, Afifi MH, Badr EA, Gehan AA (2016) The productivity of some varieties of lentil under irrigation intervals in conditions of Sinai. Int J Chem Tech Res 9(8):77-81

Kumar S, Singh R, Nayyar H (2012) a-Tocopherol application modulates the response of wheat (Triticum aestivum L.) seedlings to elevated temperatures by mitigation of stress injury and enhancement of antioxidants. J Plant Growth Regul. 32(2):307-314

Larsen P, Harbo A, Klungron S, Ashein TA (1962) On the biosynthesis of some indole compounds in Acetobacter xylinum. Physiol Plant 15:552-565

Lee G, Carrow RN, Duncan RR, Eiteman MA, Rieger MW (2008) Synthesis of organic osmolytes and salt tolerance mechanisms in Paspalum vaginatum. Environ Exp Bot 63:19-27

Lewis NG, Yamamoto E (1990) Lignin: occurrence, biosynthesis and biodegradation. Ann Rev Plant Physiol 41:455-561

Lichtenthaler HK, Buschmann C (2001) Chlorophylls and carotenoids: measurement and characterization by UV-VIS spectroscopy. In: Wrolstad RE, Acree TE, An H, Decker EA, Penner MH, Reid DS, Schwartz SJ, Shoemaker CF, Sporns $P$ (eds) Current protocols in food analytical chemistry (CPFA). Wiley, New York, p F3.1-F3.8

Maeda H, DellaPenna D (2007) Tocopherol functions in photosynthetic organisms. Curr Opin Plant Biol 10:260-265

Mahmud K, Ahmad I, Ayub M (2003) Effect of nitrogen and phosphorus on the fodder yield and quality of two sorghum cultivars (Sorghum bicolor L.). Int J Agric Biol 5:61-63 
Munamava M, Riddoch I (2001) Response of three sorghum (Sorghum bicolor $(\mathrm{L})$ Moench) varieties to soil moisture stress at different developmental stages. South Afr J Plant Soil 18(2):75-79

Munne'-Bosch, S. (2005) The role of a tocopherol in plant stress tolerance. J Plant Physiol 162:743-748

Munne-Bosch S, Alegra $L$ (2002) The function of tocopherols and tocotrienols in plants. Crit Rev Plant Sci 21:31-57

Naguib MI (1963) Colourimetric estimation of plant polysaccharides. Zeit Zucher 16:15-22

Noctor G (2006) Metabolic signaling in defense and stress: the central roles of soluble redox couples. Plant Cell Environ 29:409-425

Özbay S, Yıldırım M (2018) Root yield and quality of sugar beet under drip and sprinkler irrigation with foliar application of micronutrients. Araştırma Makalesi/Res Article 6(1):105-114

Payero JO, Melvin SR, Irmak S, Tarkalson D (2006) Yield response of corn to deficit irrigation in a semiarid climate. Agric Water Manag 84:101-112

Panel I, Farre I, Faci JM (2006) Comparative response of maize (Zea mays L) and sorghum (Sorghum bicolor L Moench) to deficit irrigation in a Mediterranean environment. Agric Water Manag 83:135-143

Radford PJ (1967) Growth analysis formulae-their use and abuse. Crop Sci 7:171-175

Rady MM, Sadak MS, El-Bassiouny HMS, Abd El-Monem AA (2011) Alleviation the adverse effects of salinity stress in sunflower cultivars using nicotinamide and a-tocopherol. Aust J Basic Appl Sci 5(10):342-355

Rady MM, Mervat SS, Safaa REL, Ebtihal MAE, Abdelhamid Magdi T (2015) Exogenous a-tocopherol has a beneficial effect on Glycine max $(\mathrm{L})$ plants irrigated with diluted sea water. J Hortic Sci Biotechnol 90(2):195-202

Ragheb HM, Gameh MA, Nafady MH, Ahmed AR (2000) Growth, yield, water use efficiency and nutrients contents of two bean varieties under trickle and sprinkler irrigation regimes in the New valley Assiut. J Agric Sci 33(2):1-24
Sadak MS, Rady MM, Badr NM, Gaballah MS (2010) Increasing sunflower salt toleramce using nicotinamide and a-tocopherol. Int J Acad Res 2:263-270

Sadak MS (2014) Mona GD (2014) Role of ascorbic acid and a tocopherol in alleviating salinity stress on flax plant (Linum usitatissimum L). J Stress Physiol Biochem 10(1):93-111

Sepaskhah and Ahmadi, M.M. (2010) Every-other-furrow irrigation with different irrigation intervals for grain sorghum. Pak J Biol Sci 11(9):1234-1239

Sher A, Barbanti L, Ansar M, Malik MA (2013) Growth response and plant water status in forage sorghum (Sorghum bicolor (L.) Moench) cultivars subjected to decreasing levels of soil moisture. Australian J Crop Sci 7(6):801-808

Snedecor GW, Cochran WG (1990) Statistical Method, 7th edn. lawa State University Press, Ames, pp 325-330

Tawfik MM, Gehan Sh, Bakhoum KMO, Thalooth AT (2018) Comparative study on some Faba bean cultivars under water limitation conditions and different sowing dates Middle East. J Agric Res 7(4):1431-1443

Vartainan N, Hervochon P, Marcotte L, Larher F (1992) Proline accumulation during drought rhizogenesis in Brassica napus var. oleifera. Plant Physiol 140:623-628

Whitfield MB, Chinn MS, Veal MW (2012) Processing of materials derived from sweet sorghum for biobased products. Ind Crops Prod 37:362-375

Yemm EW, Cocking EC (1955) The determination of amino acids with ninhydrin. Analyst 80:209-213

Yuan JS, Tiller KH, Al-Ahmad H, Stewart NR, Stewart CN Jr (2008) Plants to power: bioenergy to fuel the future. Trends Plant Sci 13:421-429

\section{Publisher's Note}

Springer Nature remains neutral with regard to jurisdictional claims in published maps and institutional affiliations.

\section{Submit your manuscript to a SpringerOpen ${ }^{\odot}$ journal and benefit from:}

- Convenient online submission

- Rigorous peer review

- Open access: articles freely available online

- High visibility within the field

- Retaining the copyright to your article

Submit your next manuscript at $\boldsymbol{\nabla}$ springeropen.com 